SLOPE AND BANK

EROSIONAL STABILITY OF THE

Canonsburg, Pennsylvania,

UMTRA DISPOSAL SITE

December 1994 


\section{INTENDED FOR PUBLIC RELEASE}

This report has been reproduced from the best available copy. Available in paper copy and microfiche.

Number of pages in this report: 40

DOE and DOE contractors can obtain copies of this report from:

Office of Scientific and Technical Information

P.O. Box 62

Oak Ridge, TN 37831

(615) 576-8401

This report is publicly available from:

National Technical Information Service

Department of Commerce

5285 Port Royal Road

Springfield, VA 22161

(703) $487-4650$ 


\title{
SLOPE AND BANK EROSIONAL STABILITY OF \\ THE CANONSBURG, PENNSYLVANIA, UMTRA DISPOSAL SITE
}

December 1994

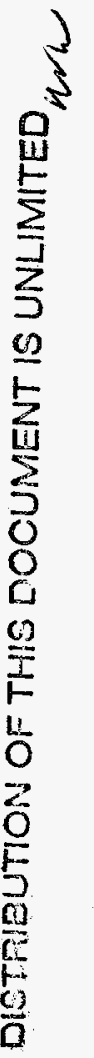

\author{
Prepared for \\ U.S. Department of Energy \\ UMTRA Project Office \\ Albuquerque, New Mexico \\ Prepared by \\ Jacobs Engineering Group Inc. \\ Albuquerque, New Mexico
}

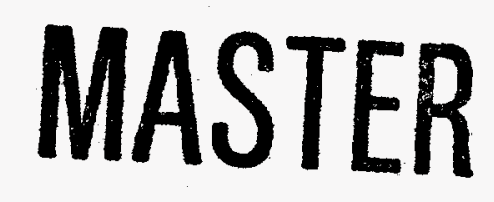

\section{DISCLAIMER}

\begin{abstract}
This report was prepared as an account of work sponsored by an agency of the United States Government. Neither the United States Government nor any agency thereof, nor any of their employees, makes any warranty, express or implied, or assumes any legal liability or responsibility for the accuracy, completeness, or usefulness of any information, apparatus, product, or process disclosed, or represents that its use would not infringe privately owned rights. Reference herein to any specific commercial product, process, or service by trade name, trademark, manufacturer, or otherwise does not necessarily constitute or imply its endorsement, recommendation, or favoring by the United States Government or any agency thereof. The views and opinions of authors expressed herein do not necessarily state or reflect those of the United States Government or any agency thereof.
\end{abstract}


TABLE OF CONTENTS

Section

Page

1.0 INTRODUCTION $\ldots \ldots \ldots \ldots \ldots \ldots \ldots \ldots \ldots \ldots \ldots \ldots \ldots \ldots \ldots$

2.0 REVIEW OF HYDRAULIC AND GEOTECHNICAL DATA $\ldots \ldots \ldots \ldots \ldots$

3.0 FLOOD LEVEL ANALYSIS OF CHARTIERS CREEK $\ldots \ldots \ldots \ldots \ldots \ldots \ldots$

4.0 EROSION ANALYSIS $\ldots \ldots \ldots \ldots \ldots \ldots \ldots \ldots \ldots \ldots \ldots \ldots \ldots \ldots \ldots$

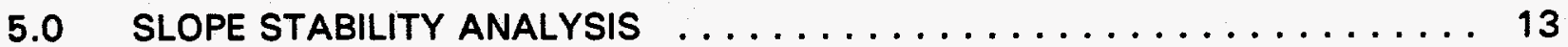

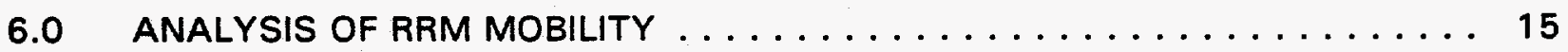

7.0 CONCLUSIONS $\ldots \ldots \ldots \ldots \ldots \ldots \ldots \ldots \ldots \ldots \ldots \ldots \ldots \ldots$

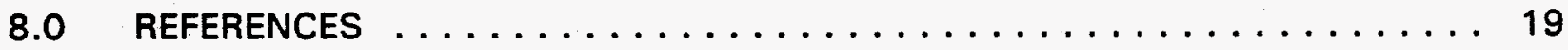
APPENDIX 


\section{LIST OF FIGURES}

\section{Figure}

Page

3.1 Location plan with cross sections, Canonsburg, Pennsylvania, site . . . . . . 6

3.2 Section A, Canonsburg, Pennsylvania, site . . . . . . . . . . . . . 7

3.3 Section B, Canonsburg, Pennsylvania, site . . . . . . . . . . . . . 8

3.4 Stability analysis critical section, Canonsburg, Pennsylvania, site . . . . . . . 9

3.5 FEMA flood map of the Canonsburg, Pennsylvania, site . . . . . . . . . . 10

4.1 Relationship between erosion rates and catchment area $\ldots \ldots \ldots \ldots \ldots$ 


\section{LIST OF TABLES}

Table

Page

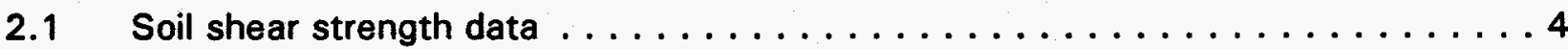




\section{LIST OF ACRONYMS}

\section{Acronym Definition}

DOE

FEMA

FIA

NRC

RRM

UMTRA

USACE

VP
U.S. Department of Energy

Federal Emergency Management Agency

Federal Insurance Administration

U.S. Nuclear Regulatory Commission

residual radioactive material

Uranium Mill Tailings Remedial Action

U.S. Army Corps of Engineers

vicinity property 


\subsection{INTRODUCTION}

This white paper was prepared in response to U.S. Nuclear Regulatory Commission (NRC) comments received in a letter of 8 March 1994. This letter included discussions of the U.S. Department of Energy (DOE) 21 May 1993 geomorphic report for the Canonsburg, Pennsylvania, site. To clarify the NRC's position, a DOE/NRC conference call was held on 12 April 1994. The NRC clarified that it did not require a preliminary erosion protection design for the Canonsburg site, but directed the DOE to address a "one-bad-year" scenario. The NRC wants confirmation that one bad year of stream flooding and landsliding will not release residual radioactive material (RRM) from the Canonsburg site into the creek. The NRC is concerned that a bad year theoretically could occur between postcell-closure inspections. These annual inspections are conducted in September or October.

The NRC suggested during the 12 April 1994 conference call that the following procedures should be conducted in this analysis:

- A flooding analysis, including the maximum saturation levels (flood water elevations) anticipated during a 100-year flood.

- A stream bank erosion analysis to determine how much of the bank adjacent to the site may be removed in a bad year.

- A slope stability analysis to determine how far back the site would be disturbed by slope instability that could be triggered by a bad year of stream bank erosion.

- A "critical cross section" study to show the relationship of the RRM located outside the disposal cell to the maximum computer estimated erosion/landslide activity.

For these analyses, Ted Johnson of NRC suggested the DOE use "best estimate" values of parameters and erosion rates and avoid the use of "worst case" scenarios to prevent unreasonable predictions.

The U.S. Army Corps of Engineers (USACE), Pittsburgh District, has begun a feasibility study of Chartiers Creek, called the Canonsburg-Houston Local Flood Protection Project, Unit 2B Reach (USACE, 1994). This USACE study covers a 1.6-mile reach of the creek in the Boroughs of Canonsburg and Houston. The project would consist of improvements to the Chartiers Creek channel which essentially includes channel excavation and stone slope protection. Portions of the Unit 2B reach adjacent to the Canonsburg Uranium Mill Tailings Remedial Action (UMTRA) site have been studied for stabilization by concrete, gravityretaining walls. The USACE will decide whether to proceed with this project in September 1995. 



\subsection{REVIEW OF HYDRAULIC AND GEOTECHNICAL DATA}

To perform slope stability and erosion analyses, information was needed on soil stratification and shear strength parameters of the soils at the Canonsburg site and the banks of Chartiers Creek.

Shear strength data prepared by MK-Ferguson Company (MK-Ferguson Company, 1986a) is given below:

- Surface cell material,

C $\quad=500$ pounds per square foot (psf)

$r_{\text {sat }}=110$ pounds per cubit foot (pcf)

- Foundations soils,

C $\quad=750$ psf

$V_{\text {sat }}=120 \mathrm{pcf}$

- Seismic coefficient,

$A_{a}=0.05$ gravity

Test boring data were reviewed to determine shear strength parameters suitable for the stability analysis of the bank of Chartiers Creek. Test borings used to evaluate soil shear strength parameters included boring numbers $3,6,412,413,414,423,424,425,505$, and 506. Table 2.1 gives drained (i.e., effective) shear strength parameters of alluvial soils derived from test boring data.

The erosion/landsliding that occurs along the banks of Chartiers Creek has been observed (DOE, 1993) to be a two-stage process. Initially during major flooding, the toe of the bank erodes, steepening the bank at its base. This continues until an unstable slope angle causes a rotational landslide (i.e., mass movement). After landsliding, the slide mass moves toward the base of the slope and remains there to be eroded by other, smaller flood events. After smaller floods expose the underlying stable bank, the entire cycle begins again.

Because the timing of these erosion/landsliding events is unknown, the actual shear strength existing on the failure surface during the slide movement may be somewhere between the drained and the undrained case. To account for likely variations in soil drainage during the erosion/sliding process, a sensitivity analysis was performed to determine the shear strength of the soil mass when its factor of safety approximates 1.0 (i.e., when a landslide is probable). Section 5.0, "Slope Stability Analysis," further describes the shear strength sensitivity analysis. 
Table 2.1 Soil shear strength data

\begin{tabular}{|c|c|c|c|}
\hline Boring number & $\begin{array}{c}\text { Stratum depth } \\
\text { (ft) }\end{array}$ & Soil type & $\begin{array}{c}\text { Friction angle } \\
\left(\Phi^{\prime}\right)\end{array}$ \\
\hline 3 & $\begin{array}{l}0-3 \\
3-7 \\
7-15\end{array}$ & $\begin{array}{l}\text { sandy clay } \\
\text { sandy clay } \\
\text { silty clay }\end{array}$ & $\begin{array}{l}31^{\circ} \\
33.5^{\circ} \\
32^{\circ}\end{array}$ \\
\hline 6 & $0-17$ & $\begin{array}{l}\text { silty clay, } \\
\text { sandy clay }\end{array}$ & $\begin{array}{l}28^{\circ} \\
29.5^{\circ}\end{array}$ \\
\hline 412 & $\begin{array}{r}0-12 \\
12-19\end{array}$ & $\begin{array}{l}\text { silty clay } \\
\text { silty clay }\end{array}$ & $\begin{array}{l}32^{\circ} \\
29.5^{\circ}\end{array}$ \\
\hline 413 & $\begin{array}{r}0-10 \\
10-12\end{array}$ & $\begin{array}{l}\text { silty clay } \\
\text { silty sand }\end{array}$ & $\begin{array}{l}31.5^{\circ} \\
27^{\circ}\end{array}$ \\
\hline 414 & $\begin{array}{r}0-3.5 \\
3.5-12 \\
12-15\end{array}$ & $\begin{array}{l}\text { sandy clay } \\
\text { silty clay } \\
\text { sandy clay }\end{array}$ & $\begin{array}{l}31^{\circ} \\
30.5^{\circ} \\
29^{\circ}\end{array}$ \\
\hline 423 & $0-9.5$ & silty clay & $31^{\circ}$ \\
\hline 424 & $\begin{array}{c}0-3 \\
3-12 \\
12-14\end{array}$ & $\begin{array}{l}\text { silty clay } \\
\text { sandy clay } \\
\text { clayey sand }\end{array}$ & $\begin{array}{l}32^{\circ} \\
29^{\circ} \\
28^{\circ}\end{array}$ \\
\hline 425 & $\begin{array}{l}0-3 \\
3-7 \\
7-15\end{array}$ & $\begin{array}{l}\text { sandy clay } \\
\text { sandy clay } \\
\text { silty clay }\end{array}$ & $\begin{array}{l}31^{\circ} \\
33.5^{\circ} \\
32^{\circ}\end{array}$ \\
\hline 505 & $\begin{array}{l}0-4 \\
4-14\end{array}$ & $\begin{array}{l}\text { silty clay } \\
\text { silty clay }\end{array}$ & $\begin{array}{l}32^{\circ} \\
28^{\circ}\end{array}$ \\
\hline 506 & $\begin{aligned} 0 & -3.5 \\
3.5 & -8 \\
8 & -12\end{aligned}$ & $\begin{array}{l}\text { silty clay } \\
\text { sandy clay } \\
\text { clayey sand }\end{array}$ & $\begin{array}{l}30.5^{\circ} \\
32^{\circ} \\
32^{\circ}\end{array}$ \\
\hline
\end{tabular}

- - degree.

$\mathrm{ft}$ - feet.

$\phi$ - effective shear strength friction angle. 


\subsection{FLOOD LEVEL ANALYSIS OF CHARTIERS CREEK}

The NRC agreed that data from a 100-year flooding event are suitable for this analysis. A 100-year storm event represents a 1-percent chance that one such flood might occur in a given year. There is also a 1-percent chance that two 10-year storms could occur in a given year, but the maximum elevation of these lesser floods and the resulting bank erosion likely would be less than from the 100-year flooding event.

The record flood (approximate elevation 962 feet $(\mathrm{ft}$ ) above mean sea level at the Canonsburg site) on Chartiers Creek occurred in September 1912 (USACE, 1994). The distance from the centerline of Chartiers Creek to the 1912 high-water mark adjacent to the UMTRA cell at critical section A is approximately $240 \mathrm{ft}$. The 1912 flood of record would have just reached the toe of the vicinity property (VP) material deposited in the supplemental disposal mound near the northwest corner of the site.

The location plan (Figure 3.1) shows the cross sections analyzed (Figures 3.2 and 3.3). Section A (Figure 3.2) was taken from the as-built site grading plan (MK-Ferguson Company, 1986b). The "critical section A" included on Figure 3.4 was generated by actual field survey data obtained along section $A$ by Mounts Engineering Company, Washington, Pennsylvania. Section A was selected as the critical section because the current active erosion at Chartiers Creek is closer to the VP mound (which contains RRM) at this location (Figure 3.1) than to any other part of the site.

The Federal Emergency Management Agency (FEMA) and Federal Insurance Administration (FIA) flood insurance study for the Borough of Canonsburg, Pennsylvania, Washington County, Community number 420849 (FEMA/FIA, 1979) includes a cross section (cross section $N$ ) that approximates section A (Figure 3.5). The FEMA 100-year-flood level at section $A$ is at elevation $949.6 \mathrm{ft}$, and the flood velocity is 4.6 feet per second $(\mathrm{ft} / \mathrm{s})$. FIA regulations do not allow construction in or modifications of river flood plain areas that will raise the floodway's 100-year-flood level by more than $1.0 \mathrm{ft}$ (FEMA/FIA, 1979) (i.e., to elevation $950.6 \mathrm{ft}$ at section A).

The FEMA 100 -year-flood level and the statutory level of 100 years plus $1.0 \mathrm{ft}$ is plotted on the critical section included in Figure 3.4. As can been seen from this section, both the 100 -year-flood elevation of $949.6 \mathrm{ft}$ and the statutory level of $950.6 \mathrm{ft}$ do not exceed the banks of the existing Chartiers Creek channel, and would not even reach the perimeter fence along the west side of the Canonsburg UMTRA site. Review of the Canonsburg as-built site grading plan (MK-Ferguson Company, 1986b) indicates that no RRM is affected by 100-year flooding in areas A, B, the residential area, or the industrial area (i.e., all of the site west of Strabane Avenue). Review of as-built grading in area $C$ (east of Strabane Avenue) indicates most of this area would be under water during a 100-year flood, but area $C$ does not contain RRM that is vulnerable to removal by surface erosion. 


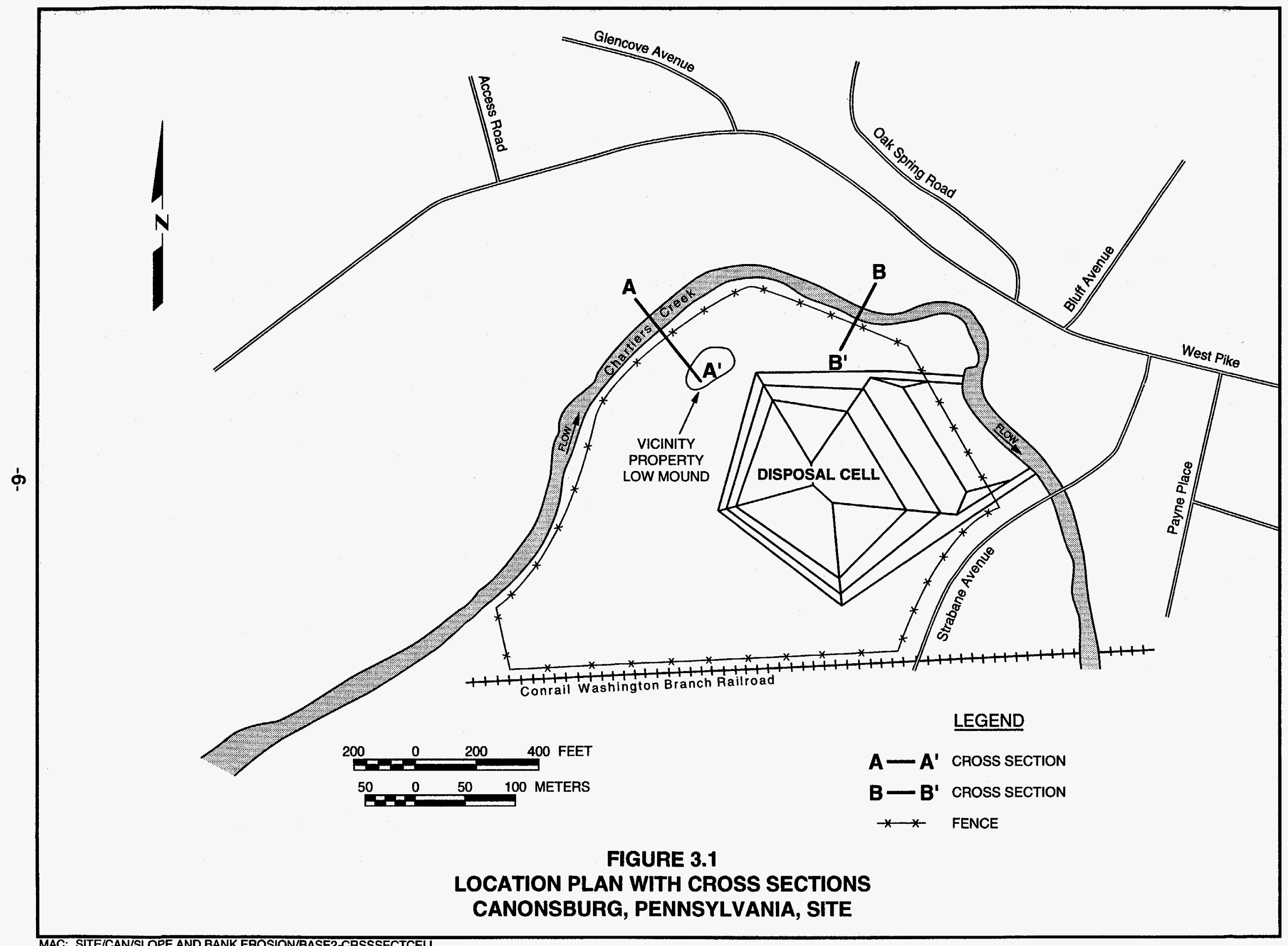




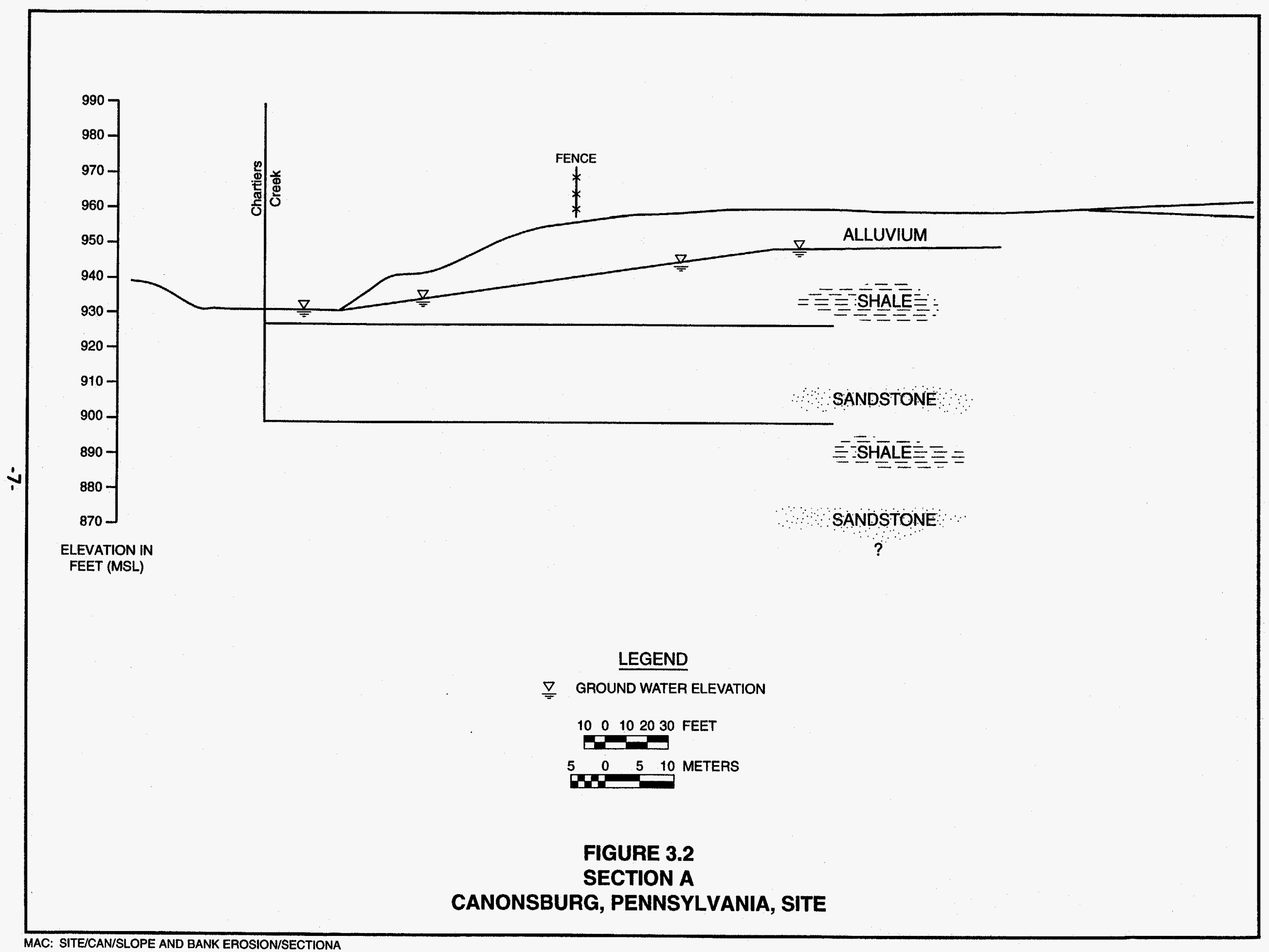




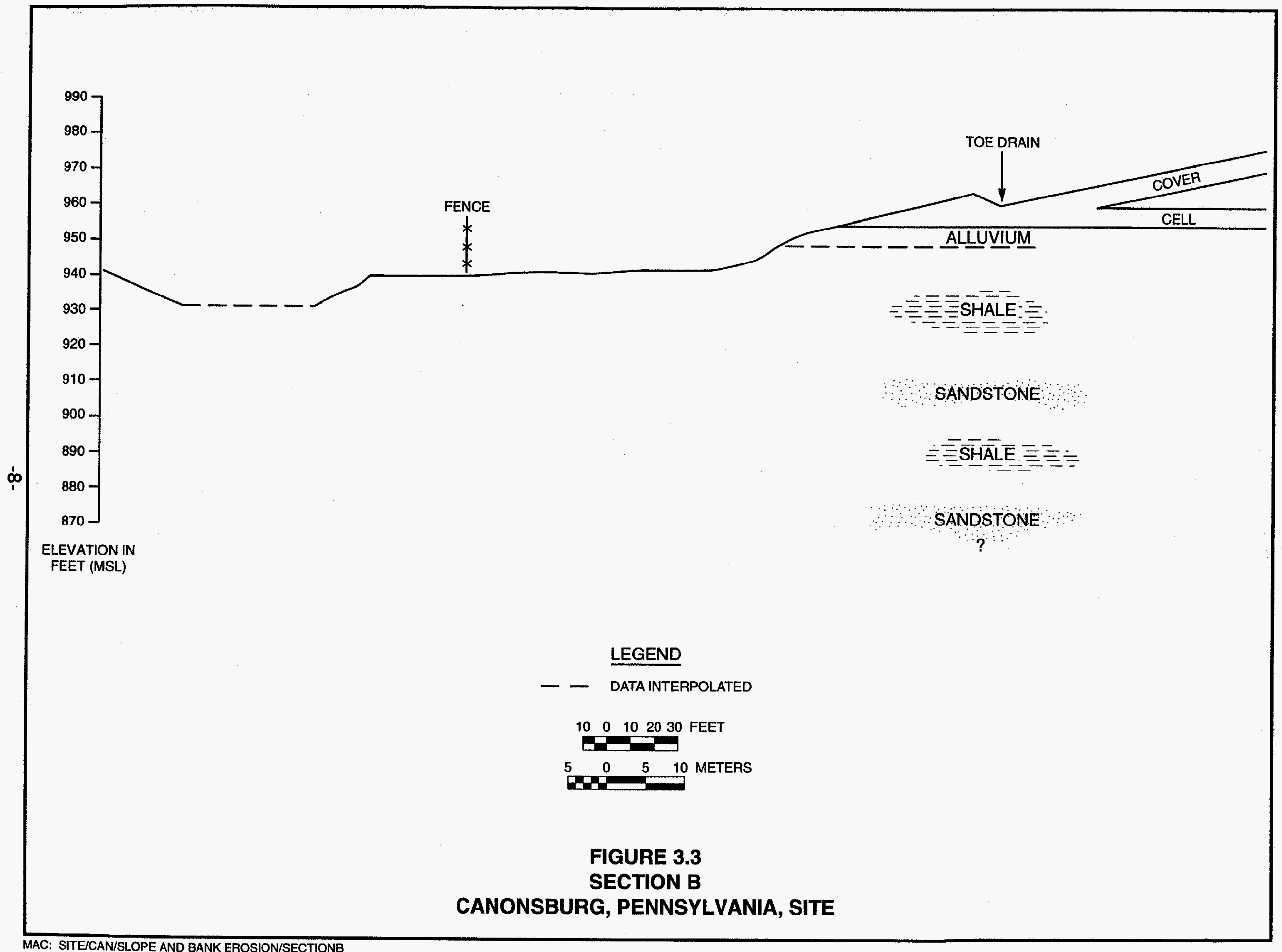




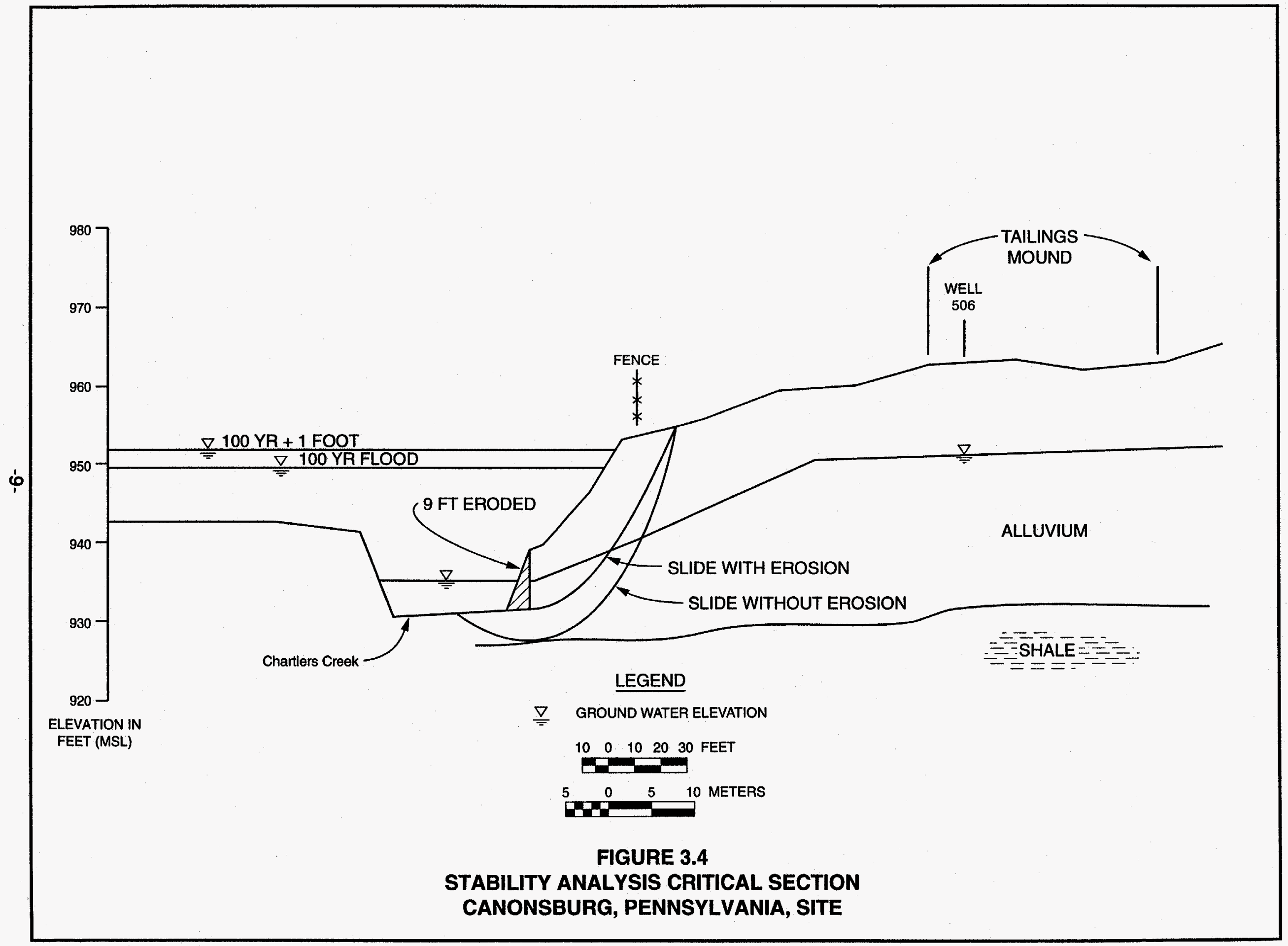




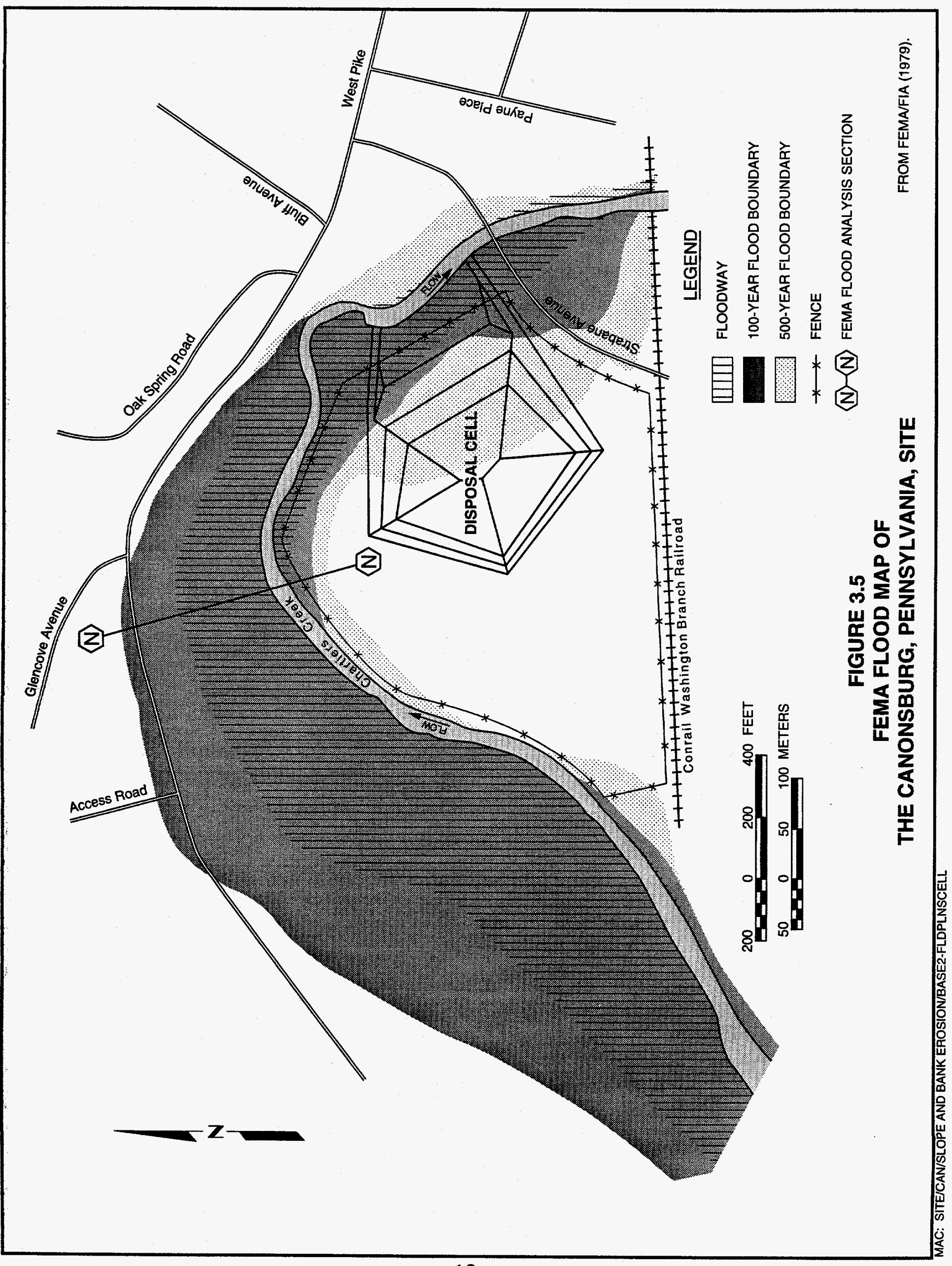




\subsection{EROSION ANALYSIS}

Channel design equations for erosion control frequently consider either the maximum permissible flow velocity or the critical tractive force (Kirkby and Morgan, 1980). These design equations provide data to determine whether erosion will occur or if erosion will be within acceptable limits. These channel erosion design equations are not used to determine how much side-bank erosion may occur in a given year.

A literature search was conducted to find reports of stream bank erosion rates in temperate climate areas similar to Pennsylvania. In 1980, J. M. Hooke published a report on stream-bank erosion rates (Hooke, 1980). Hooke's paper includes stream erosion data from Europe and the eastern United States, including Pennsylvania. Stream erosion data in Hooke's paper is for meandering streams only (i.e., similar to Chartiers Creek); data for braided streams were excluded. Hooke used two types of stream-bank erosion data: field measurements covering time spans from 1 to 10 years, and map and aerial photograph comparisons covering time spans from 10 to 200 years. Hooke found a correlation between the expected annual rate of stream-bank erosion and the catchment area of the stream; a plot of the data supporting this finding is included in his 1980 paper.

Using data of stream-bank erosion from Hooke's paper (Hooke, 1980), upper and lower bounds on the expected annual stream-bank erosion on Chartiers Creek were estimated (Figure 4.1). Given that the Chartiers Creek drainage area is approximately 91 square miles (FEMA/FIA, 1979), the lower bound yearly bank erosion would be approximately 3 inches per year and the upper bound value would be approximately $9 \mathrm{ft}$ per year. The $9 \mathrm{ft}$ per year side-bank erosion rate was used in developing the "one bad year" scenario analysis requested by NRC (see Sections 5.0 and 6.0 below). 


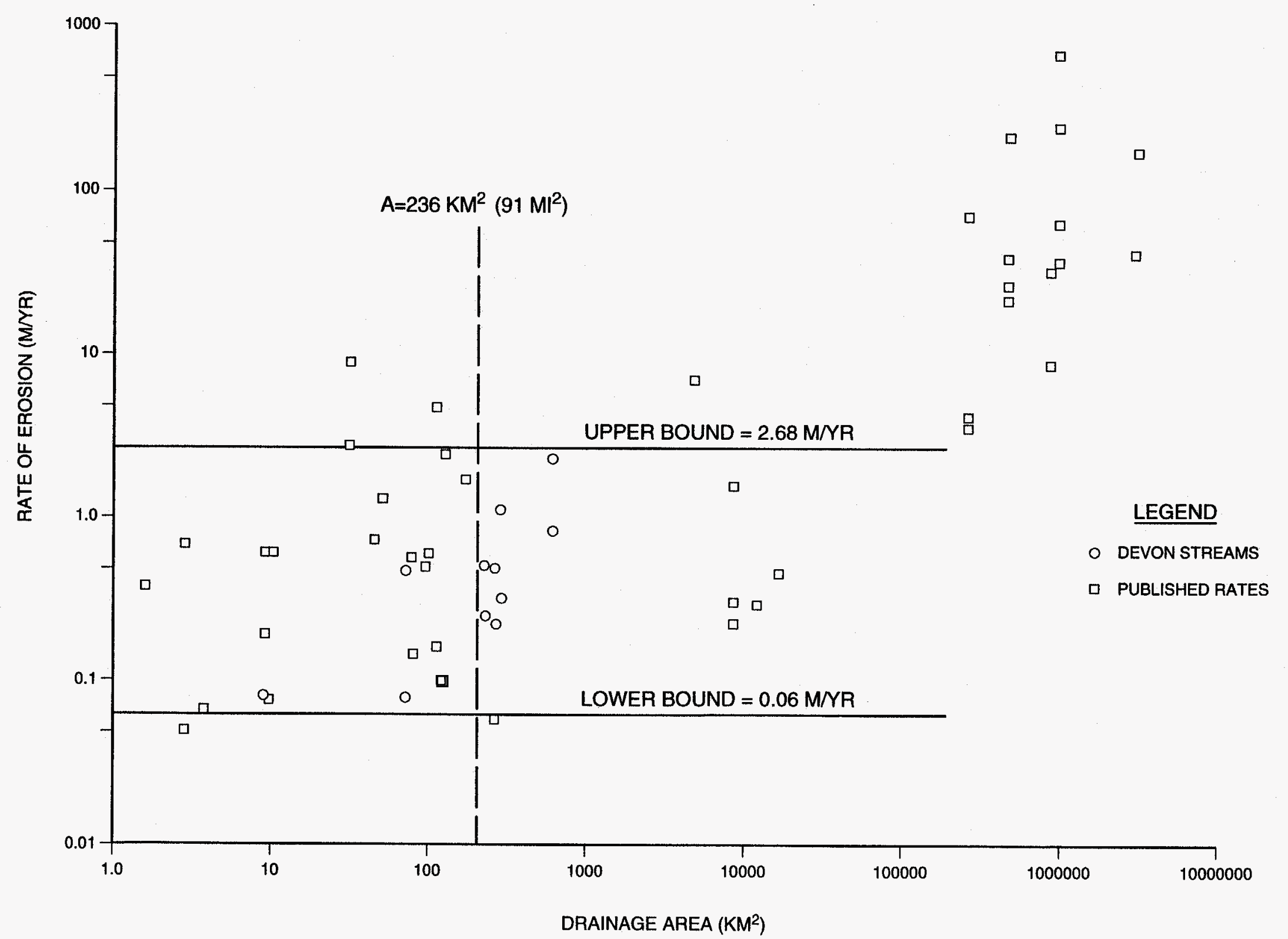

MODIFIED FROM HOOKE (1979)

FIGURE 4.1

RELATIONSHIP BETWEEN EROSION RATES AND CATCHMENT AREA 


\subsection{SLOPE STABILITY ANALYSIS}

A sensitivity analysis was performed to determine the angle of internal friction, $\Phi$, that would simulate shear strength of the "toe erosion-rotational slide" mechanism at failure; i.e., when the calculated factor of safety is approximately equal to 1.0. Based on the results of this analysis, a design friction angle of 26 degrees was determined.

Using the actual field geometry along critical section A (surveyed by Mounts Engineering Company in July 1994) and assuming that a wedge of soil $9 \mathrm{ft}$ wide at its base is eroded from the bank, the STABL5 program (Carpenter, 1986) was used to determine the location of likely failure surfaces that would be generated. The minimum factor of safety surface is plotted in Figure 3.4.

The upper end of the slide mass is $82 \mathrm{ft}$ from the centerline of Chartiers Creek and is approximately $100 \mathrm{ft}$ from the toe of the VP mound (Figure 3.4). The fence would be damaged by the slide movement, and should be easily spotted by prelicensing inspection personnel.

When the slide movement occurs, the lower portion of the slide mass will move into the Chartiers Creek channel, and the upper portion of the slide mass will drop down several feet. The lower portion of the slide mass must be removed by stream erosion before the upper portion can drop down into the reach of annual flood waters.

Observations since 1992 of bank slides north and west of the disposal cell and slides along the perimeter of area $C$ indicate that a slide's mass is not immediately removed by Chartiers Creek. Instead, the slide material is removed slowly by smaller-magnitude floods that occur predominately in fall and spring. One rather large slide observed along the north side of area $C$ required approximately 2 years for the entire slide mass to remove from the stream channel. 


\subsection{ANALYSIS OF RRM MOBILITY}

The NRC requested an analysis of the potential movement of RRM off the Canonsburg site in the bad year, scenario defined in Section 1.0. NRC agreed to use a 100-year flood event for this analysis, which represents a 1-percent chance that such a scenario could happen in a given year.

Review of the available flooding analyses indicates that the 100 picocuries per gram RRM placed on the west side of the disposal cell beneath $2 \mathrm{ft}$ of cover is well above the 100year flood plain and could not be eroded or removed by the flood waters. The 1912 maximum flood of record on Chartiers Creek reached an elevation of approximately $962 \mathrm{ft}$, which just reaches the toe of the VP mound but does not cover the western side of the site. Based on this data, removal of RRM from the Canonsburg site by flooding is not predicted.

The flooding erosion/landsliding scenario predicts that the perimeter fence of the Canonsburg site could be damaged in one bad year, but RRM would not be removed from the site. Because the landslide mass probably would not be totally removed in one year, the DOE should have adequate time to identify and correct a slide problem before a second bad-year scenario occurred. 


\subsection{CONCLUSIONS}

The findings of the analyses included in this report are summarized below:

- The maximum flood level anticipated at the Canonsburg site during a 100 year flood event was determined to be elevation $950.6 \mathrm{ft}$. This flood elevation is well below the elevation of RRM placed outside the disposal cell but inside the controlled area on the Canonsburg site.

- Bank erosion and landslide movement of soil during a bad year was determined to include a section of the Chartiers Creek bank that extends approximately $82 \mathrm{ft}$ from the centerline of the stream toward the existing VP mound (Figure 3.4). The predicted soil movement would extend approximately 10 to $12 \mathrm{ft}$ inside the existing perimeter fence, but would still be approximately 95 to $100 \mathrm{ft}$ from the edge of the VP mound.

Findings of the erosion and landslide analyses performed for the Canonsburg site indicate RRM would not be removed from the containment area by natural erosion or mass wasting processes in the periods between annual site inspections. 



\subsection{REFERENCES}

Carpenter, J. R., 1986. "STABL5/PCSTABL5 USER MANUAL", School of Civil Engineering, Purdue University, West Lafayette, Indiana.

DOE (U.S. Department of Energy), 1993. Geomorphic Stability Field Reconnaissance Site Visit, December 1992, U.S. Department of Energy, UMTRA Project Office, Albuquerque Operations Office, Albuquerque, New Mexico.

FEMA/FIA (Federal Emergency Management Agency/Federal Insurance Administration), 1979. Flood Insurance Study, Borough of Canonsburg, Pennsylvania, Washington County, FEMA Community Number 420849.

Hooke, J. M., 1980, "Magnitude and Distribution of Rates of River Bank Erosion," Earth Surface Processes, John Wiley \& Sons Ltd., Vol. 5, pp.143-157.

Kirkby, M. J., and R. P. C. Morgan, 1980. Soil Erosion, M. J. Kirkby and R. P. C. Morgan, eds., John Wiley \& Sons, pp. 271-272.

MK-Ferguson Company, 1986a. "Encapsulation all Stability Analysis," Canonsburg Uranium Mill Tailings Site Remedial Action Completion Report, final version, October 1986, Volume 3, p. 2.

MK-Ferguson Company (formerly International Engineering Company, Inc.), 1986b. "AsBuilt, Site Grading Plan, Drawing Number CAN-PS-10-0045," October 14, 1986.

USACE (U.S. Army Corps of Engineers), 1994. "Chartiers Creek, Canonsburg, Houston Unit 2B, General Reevaluation Report, Initial Project Management Plan, May 1994, Revised July 1994, U.S. Army Corps of Engineers, Pittsburg District. 
APPENDIX 
by

Purdue University

- -Slope Stability Analysis--

Simplified Janbu, Simplified Bishop

or Spencer's Method of Slices

Run Date:

Time of Run:

Run By:

Input Data Filename:

Output Filename:

Plotted Output Filename:
$12-09-94$

$8: 37$ am

John Lommler

A: CANON. E11

A: CANON. OUT

A: CANON. PLT

PROBLEM DESCRIPTION

Canonsburg, Mounts, Section A w/erosion Soil 26.0 deg \& 120 pcf, $E Q=0.0 \mathrm{~g}$

BOUNDARY COORDINATES

15 Top Boundaries

16 Total Boundaries

$\begin{array}{cccccc}\begin{array}{c}\text { Boundary } \\ \text { No. }\end{array} & \begin{array}{c}\text { X-Left } \\ (\mathrm{ft})\end{array} & \begin{array}{c}\text { Y-Left } \\ (\mathrm{ft})\end{array} & \begin{array}{c}\text { X-Right } \\ (\mathrm{ft})\end{array} & \begin{array}{c}\text { Y-Right } \\ (\mathrm{ft})\end{array} & \begin{array}{c}\text { Soil Type } \\ \text { Below Bnd }\end{array} \\ 1 & \begin{array}{l}.00 \\ 2\end{array} & 22.00 & 29.90 & 22.20 & 1 \\ 2 & 29.90 & 22.20 & 30.00 & 29.40 & 1 \\ 3 & 30.00 & 29.40 & 37.00 & 30.00 & 1 \\ 4 & 37.00 & 30.00 & 51.50 & 35.70 & 1 \\ 5 & 51.50 & 35.70 & 64.00 & 43.20 & 1 \\ 6 & 64.00 & 43.20 & 67.50 & 43.40 & 1 \\ 7 & 67.50 & 43.40 & 71.00 & 44.00 & 1 \\ 8 & 71.00 & 44.00 & 97.00 & 46.50 & 1 \\ 9 & 97.00 & 46.50 & 125.50 & 49.40 & 1 \\ 10 & 125.50 & 49.40 & 153.00 & 50.70 & 1 \\ 11 & 153.00 & 50.70 & 180.00 & 52.50 & 1 \\ 12 & 180.00 & 52.50 & 209.00 & 53.20 & 1 \\ 13 & 209.00 & 53.20 & 239.00 & 52.00 & 1 \\ 14 & 239.00 & 52.00 & 266.50 & 53.00 & 1 \\ 15 & 266.50 & 53.00 & 293.00 & 54.30 & 1 \\ 16 & .00 & 18.00 & 295.00 & 18.20 & 2\end{array}$


2 Type(s) of soil

Soil Total Saturated Cohesion Friction Pore Pressure Piez. Type Unit Wt. Unit Wt. Intercept Angle Pressure Constant Surface No. (pcf) (pcf) (psf) (deg) Param. (psf) No.

\begin{tabular}{|c|c|c|}
\hline 115.0 & 120.0 & \\
\hline
\end{tabular}

1 PIEZOMETRIC SURFACE(S) HAVE BEEN SPECIFIED

Unit Weight of water $=62.40$

Piezometric Surface No. 1 Specified by 4 Coordinate Points

$\begin{array}{crc}\begin{array}{c}\text { Point } \\ \text { No. }\end{array} & \begin{array}{c}\text { X-Water } \\ \text { (ft) }\end{array} & \begin{array}{c}\text { Y-Water } \\ \text { (ft) }\end{array} \\ 1 & & \\ 2 & 25.00 & 26.00 \\ 3 & 144.00 & 26.00 \\ 4 & 295.00 & 40.20 \\ & & 52.00\end{array}$

Searching Routine will Be Limited To An Area Defined By 1 Boundaries of Which The First 1 Boundaries Will Deflect Surfaces Upward

$\begin{array}{crrrr}\begin{array}{c}\text { Boundary } \\ \text { No. }\end{array} & \begin{array}{c}\text { X-Left } \\ (\mathrm{ft})\end{array} & \begin{array}{c}Y \text {-Left } \\ (\mathrm{ft})\end{array} & \begin{array}{c}\mathrm{X}-\mathrm{R} \text { ight } \\ (\mathrm{ft})\end{array} & \begin{array}{c}\mathrm{Y} \text {-Right } \\ (\mathrm{ft})\end{array} \\ 1 & .00 & .00 & 295.00 & .10\end{array}$

A Critical Failure Surface Searching Method, Using A Random Technique For Generating Circular surfaces, Has Been specified.

200 Trial Surfaces Have Been Generated.

20 Surfaces Initiate From Each of 10 Points Equally Spaced Along The Ground Surface Between $x=.00 \mathrm{ft}$. 
and $x=30.00 \mathrm{ft}$.

Each Surface Terminates Between $X=71.00 \mathrm{ft}$.

and $X=125.50 \mathrm{ft}$.

Unless Further Limitations Were Imposed, The Minimum Elevation At Which A Surface Extends Is $Y=.00 \mathrm{ft}$.

6.00 ft. Line Segments Define Each Trial Failure Surface.

Restrictions Have Been Imposed Upon The Angle of Initiation. The Angle Has Been Restricted Between The Angles of -45.0 And $32.0 \mathrm{deg}$.

Following Are Displayed The Ten Most Critical of The Trial Failure Surfaces Examined. They Are Ordered - Most Critical First.

* * Safety Factors Are Calculated By The Modified Bishop Method * *

Failure Surface specified By 12 Coordinate Points

$\begin{array}{ccc}\begin{array}{c}\text { Point } \\ \text { No. }\end{array} & \begin{array}{c}\text { X-Surf } \\ \text { (ft) }\end{array} & \begin{array}{c}\text { Y-Surf } \\ \text { (ft) }\end{array} \\ 1 & 16.67 & 22.11 \\ 2 & 22.63 & 21.49 \\ 3 & 28.63 & 21.47 \\ 4 & 34.61 & 22.05 \\ 5 & 40.49 & 23.23 \\ 6 & 46.22 & 25.00 \\ 7 & 51.75 & 27.33 \\ 8 & 57.01 & 30.21 \\ 9 & 61.96 & 33.61 \\ 10 & 66.54 & 37.48 \\ 11 & 70.71 & 41.80 \\ 12 & 72.56 & 44.15\end{array}$

Circle Center At $\mathrm{X}=25.9 ; \mathrm{Y}=80.7$ and Radius, 59.3 $\star \star \star * 1.000 \quad * \star *$ 
Individual data on the 20 slices

\begin{tabular}{|c|c|c|c|c|c|c|c|c|c|}
\hline & & & $\begin{array}{l}\text { Water } \\
\text { Force }\end{array}$ & $\begin{array}{l}\text { Water } \\
\text { Force }\end{array}$ & $\begin{array}{l}\text { Tie } \\
\text { Force }\end{array}$ & $\begin{array}{l}\text { Tie } \\
\text { Force }\end{array}$ & \multicolumn{3}{|c|}{ Surcharge } \\
\hline $\begin{array}{c}\text { Slice } \\
\text { No. }\end{array}$ & $\begin{array}{l}\text { Width } \\
\text { Ft (m) }\end{array}$ & $\begin{array}{l}\text { Weight } \\
\text { Lbs (kg) }\end{array}$ & $\begin{array}{c}\text { Top } \\
\text { Lbs (kq) }\end{array}$ & $\begin{array}{l}\text { Bot } \\
\text { Lbs (kg) }\end{array}$ & $\begin{array}{c}\text { Norm } \\
\text { Lbs }(\mathrm{kg})\end{array}$ & $\begin{array}{c}\text { Tan } \\
\text { Lbs (kg) }\end{array}$ & $\begin{array}{c}\text { Hor } \\
\text { Lbs (kg) }\end{array}$ & $\begin{array}{c}\text { Ver } \\
\text { Lbs (kq) }\end{array}$ & $\begin{array}{l}\text { Load } \\
\text { Lbs (kg) }\end{array}$ \\
\hline $\begin{array}{c}\text { No. } \\
1\end{array}$ & $\begin{array}{r}6.0 \\
6.0\end{array}$ & $\begin{array}{c}\text { Los (kg) } \\
238.0\end{array}$ & 1440.5 & 1572.8 & $\begin{array}{r}\text { Wos (kg) } \\
.0\end{array}$ & $\begin{array}{r}\operatorname{Los}(\mathrm{kg}) \\
.0\end{array}$ & $\begin{array}{r}\text { Los (kg) } \\
.0\end{array}$ & $\begin{array}{r}\operatorname{Los}(\mathrm{kg}) \\
.0\end{array}$ & $\begin{array}{r}\mathrm{Lbs}(\mathrm{kg}) \\
.0\end{array}$ \\
\hline 2 & 2.9 & 233.6 & 686.4 & 807.9 & .0 & .0 & .0 & .0 & .0 \\
\hline 3 & 3.1 & 267.0 & 777.2 & 916.0 & .0 & .0 & .0 & .0 & .0 \\
\hline 4 & 1.3 & 101.5 & 333.3 & 387.9 & .0 & .0 & .0 & .0 & .0 \\
\hline 5 & .1 & 50.5 & 313.7 & 30.7 & .0 & .0 & .0 & .0 & .0 \\
\hline 6 & 4.6 & 4231.9 & .0 & 1431.3 & .0 & .0 & .0 & .0 & .0 \\
\hline 7 & 2.4 & 2153.4 & .0 & 748.2 & .0 & .0 & .0 & .0 & .0 \\
\hline 8 & 3.5 & 3213.5 & .0 & 1037.9 & .0 & .0 & .0 & .0 & .0 \\
\hline 9 & 5.7 & 5643.9 & .0 & 1496.9 & .0 & .0 & .0 & .0 & .0 \\
\hline 10 & 5.3 & 5260.2 & .0 & 954.1 & .0 & .0 & .0 & .0 & .0 \\
\hline 11 & .2 & 246.2 & .0 & 31.1 & .0 & .0 & .0 & .0 & .0 \\
\hline 12 & 4.2 & 4233.1 & .0 & 271.9 & .0 & .0 & .0 & .0 & .0 \\
\hline 13 & 1.0 & 1026.8 & .0 & .0 & .0 & .0 & .0 & .0 & .0 \\
\hline 14 & 4.9 & 4883.6 & .0 & .0 & .0 & .0 & .0 & .0 & .0 \\
\hline 15 & 2.0 & 1904.1 & .0 & .0 & .0 & .0 & .0 & .0 & .0 \\
\hline 16 & 2.5 & 2006.7 & .0 & .0 & .0 & .0 & .0 & .0 & .0 \\
\hline 17 & 1.0 & 594.7 & .0 & .0 & .0 & .0 & .0 & .0 & .0 \\
\hline 18 & 3.2 & 1305.8 & .0 & .0 & .0 & .0 & .0 & .0 & .0 \\
\hline 19 & .3 & 66.7 & .0 & .0 & .0 & .0 & .0 & .0 & .0 \\
\hline 20 & 1.6 & 164.4 & .0 & .0 & .0 & .0 & .0 & .0 & .0 \\
\hline
\end{tabular}

Failure Surface Specified By 11 Coordinate Points

$\begin{array}{ccc}\begin{array}{c}\text { Point } \\ \text { No. }\end{array} & \begin{array}{c}\text { X-Surf } \\ (\mathrm{ft})\end{array} & \begin{array}{c}\text { Y-Surf } \\ (\mathrm{ft})\end{array} \\ 1 & 23.33 & 22.16 \\ 2 & 29.28 & 21.35 \\ 3 & 35.28 & 21.29 \\ 4 & 41.24 & 21.98 \\ 5 & 47.07 & 23.40 \\ 6 & 52.68 & 25.54 \\ 7 & 57.97 & 28.35 \\ 8 & 62.88 & 31.81 \\ 9 & 67.32 & 35.84 \\ 10 & 71.23 & 40.40 \\ 11 & 73.79 & 44.27\end{array}$

Circle Center At $\mathrm{X}=32.8 ; \mathrm{Y}=69.4$ and Radius, 48.2

$\star \star \star \quad 1.048$ 
Failure Surface Specified By 13 Coordinate Points

$\begin{array}{ccc}\begin{array}{c}\text { Point } \\ \text { No. }\end{array} & \begin{array}{c}\text { X-Surf } \\ \text { (ft) }\end{array} & \begin{array}{c}\text { Y-Surf } \\ \text { (ft) }\end{array} \\ 1 & 16.67 & 22.11 \\ 2 & 22.38 & 20.28 \\ 3 & 28.29 & 19.23 \\ 4 & 34.28 & 19.00 \\ 5 & 40.26 & 19.58 \\ 6 & 46.09 & 20.97 \\ 7 & 51.69 & 23.13 \\ 8 & 56.94 & 26.03 \\ 9 & 61.75 & 29.62 \\ 10 & 66.03 & 33.82 \\ 11 & 69.70 & 38.57 \\ 12 & 72.70 & 43.77 \\ 13 & 72.87 & 44.18\end{array}$

Circle Center At $\mathrm{X}=33.0 ; \mathrm{Y}=63.2$ and Radius, 44.2 ** $\quad 1.052 \quad$ ***

Failure Surface Specified By 13 Coordinate Points

$\begin{array}{rcc}\begin{array}{c}\text { Point } \\ \text { No. }\end{array} & \begin{array}{c}\text { X-Surf } \\ \text { (ft) }\end{array} & \begin{array}{c}\text { Y-Surf } \\ \text { (ft) }\end{array} \\ 1 & 16.67 & 22.11 \\ 2 & 22.40 & 20.33 \\ 3 & 28.31 & 19.31 \\ 4 & 34.30 & 19.06 \\ 5 & 40.28 & 19.60 \\ 6 & 46.14 & 20.90 \\ 7 & 51.78 & 22.95 \\ 8 & 57.10 & 25.71 \\ 9 & 62.02 & 29.14 \\ 10 & 66.46 & 33.19 \\ 11 & 70.33 & 37.77 \\ 12 & 73.58 & 42.81 \\ 13 & 74.29 & 44.32\end{array}$

Circle Center At $\mathrm{X}=33.2 ; \mathrm{Y}=65.2$ and Radius, 46.2

*** $1.062 \quad$ ***


Failure Surface Specified By 14 Coordinate Points

$\begin{array}{ccc}\begin{array}{c}\text { Point } \\ \text { No. }\end{array} & \begin{array}{c}\text { X-Surf } \\ \text { (ft) }\end{array} & \begin{array}{c}\text { Y-Surf } \\ \text { (ft) }\end{array} \\ 1 & & \\ 2 & 6.67 & 22.04 \\ 3 & 12.58 & 21.01 \\ 4 & 18.55 & 20.45 \\ 5 & 24.55 & 20.38 \\ 6 & 30.54 & 20.79 \\ 7 & 36.47 & 21.68 \\ 8 & 42.31 & 23.04 \\ 9 & 48.03 & 24.87 \\ 10 & 53.58 & 27.15 \\ 11 & 58.93 & 29.87 \\ 12 & 64.04 & 33.01 \\ 13 & 68.88 & 36.55 \\ 14 & 73.42 & 40.47 \\ & 77.52 & 44.63\end{array}$

Circle Center At $\mathrm{X}=22.5 ; \mathrm{Y}=94.9$ and Radius, 74.6

** $\quad 1.066 \quad$ ** *

Failure Surface Specified By 15 Coordinate Points

$\begin{array}{ccc}\begin{array}{c}\text { Point } \\ \text { No. }\end{array} & \begin{array}{c}\text { X-Surf } \\ \text { (ft) }\end{array} & \begin{array}{c}\text { Y-Surf } \\ \text { (ft) }\end{array} \\ 1 & 6.67 & 22.04 \\ 2 & 12.43 & 20.38 \\ 3 & 18.33 & 19.28 \\ 4 & 24.31 & 18.77 \\ 5 & 30.31 & 18.83 \\ 6 & 36.27 & 19.48 \\ 7 & 42.15 & 20.71 \\ 8 & 47.87 & 22.49 \\ 9 & 53.40 & 24.83 \\ 10 & 58.67 & 27.70 \\ 11 & 63.64 & 31.06 \\ 12 & 68.26 & 34.89 \\ 13 & 72.49 & 39.15 \\ 14 & 76.28 & 43.80 \\ 15 & 76.78 & 44.56\end{array}$


Circle Center At $\mathrm{X}=26.6 ; \mathrm{Y}=80.4$ and Radius, 61.7 $\star * * \quad 1.069 \quad * * *$

Failure Surface Specified By 15 Coordinate Points

$\begin{array}{crc}\begin{array}{c}\text { Point } \\ \text { No. }\end{array} & \begin{array}{c}\text { X-Surf } \\ \text { (ft) }\end{array} & \begin{array}{c}\text { Y-Surf } \\ \text { (ft) }\end{array} \\ 1 & .00 & 22.00 \\ 2 & 5.86 & 20.71 \\ 3 & 11.80 & 19.87 \\ 4 & 17.79 & 19.50 \\ 5 & 23.79 & 19.60 \\ 6 & 29.76 & 20.16 \\ 7 & 35.67 & 21.19 \\ 8 & 41.49 & 22.67 \\ 9 & 47.17 & 24.61 \\ 10 & 52.68 & 26.97 \\ 11 & 57.99 & 29.76 \\ 12 & 63.07 & 32.95 \\ 13 & 67.89 & 36.53 \\ 14 & 72.41 & 40.48 \\ 15 & 76.38 & 44.52\end{array}$

Circle Center At $\mathrm{X}=19.5 ; \mathrm{Y}=96.6$ and Radius, 77.1

*** $\quad 1.082 \quad * * *$

Failure Surface Specified By 14 Coordinate Points

$\begin{array}{rcc}\begin{array}{c}\text { Point } \\ \text { No. }\end{array} & \begin{array}{c}\text { X-Surf } \\ \text { (ft) }\end{array} & \begin{array}{c}\text { Y-Surf } \\ \text { (ft) }\end{array} \\ 1 & 13.33 & 22.09 \\ 2 & 19.02 & 20.18 \\ 3 & 24.89 & 18.92 \\ 4 & 30.86 & 18.32 \\ 5 & 36.86 & 18.39 \\ 6 & 42.81 & 19.12 \\ 7 & 48.65 & 20.52 \\ 8 & 54.29 & 22.55 \\ 9 & 59.68 & 25.20 \\ 10 & 64.73 & 28.44\end{array}$




$\begin{array}{lll}11 & 69.39 & 32.22 \\ 12 & 73.60 & 36.49 \\ 13 & 77.31 & 41.20 \\ 14 & 79.56 & 44.82\end{array}$

Circle Center At $\mathrm{X}=33.2 ; \mathrm{Y}=71.9$ and Radius, 53.7

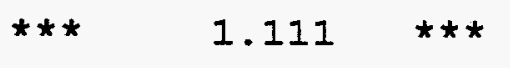

Failure Surface Specified By 13 Coordinate Points

$\begin{array}{ccc}\begin{array}{c}\text { Point } \\ \text { No. }\end{array} & \begin{array}{c}\text { X-Surf } \\ \text { (ft) }\end{array} & \begin{array}{c}\text { Y-Surf } \\ \text { (ft) }\end{array} \\ 1 & 20.00 & 22.13 \\ 2 & 25.89 & 20.97 \\ 3 & 31.86 & 20.45 \\ 4 & 37.86 & 20.56 \\ 5 & 43.82 & 21.30 \\ 6 & 49.66 & 22.68 \\ 7 & 55.32 & 24.66 \\ 8 & 60.74 & 27.24 \\ 9 & 65.85 & 30.38 \\ 10 & 70.60 & 34.04 \\ 11 & 74.94 & 38.18 \\ 12 & 78.81 & 42.77 \\ 13 & 80.25 & 44.89\end{array}$

Circle Center At $\mathrm{X}=33.8 ; \mathrm{Y}=76.8$ and Radius, 56.4

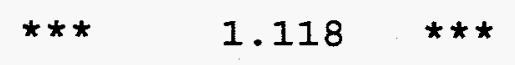

Failure Surface Specified By 15 Coordinate Points

$\begin{array}{ccc}\begin{array}{c}\text { Point } \\ \text { No. }\end{array} & \begin{array}{c}\text { X-Surf } \\ \text { (ft) }\end{array} & \begin{array}{c}\text { Y-Surf } \\ \text { (ft) }\end{array} \\ & & \\ 1 & 10.00 & 22.07 \\ 2 & 15.84 & 20.71 \\ 3 & 21.78 & 19.86 \\ 4 & 27.77 & 19.52 \\ 5 & 33.77 & 19.71 \\ 6 & 39.73 & 20.41 \\ 7 & 45.61 & 21.62\end{array}$




$\begin{array}{rll}8 & 51.35 & 23.34 \\ 9 & 56.93 & 25.55 \\ 10 & 62.30 & 28.23 \\ 11 & 67.42 & 31.37 \\ 12 & 72.24 & 34.93 \\ 13 & 76.74 & 38.90 \\ 14 & 80.88 & 43.24 \\ 15 & 82.36 & 45.09\end{array}$

Circle Center At $\mathrm{X}=28.6 ; \mathrm{Y}=88.9$ and Radius, 69.4 ** $\quad 1.121 \quad * * *$

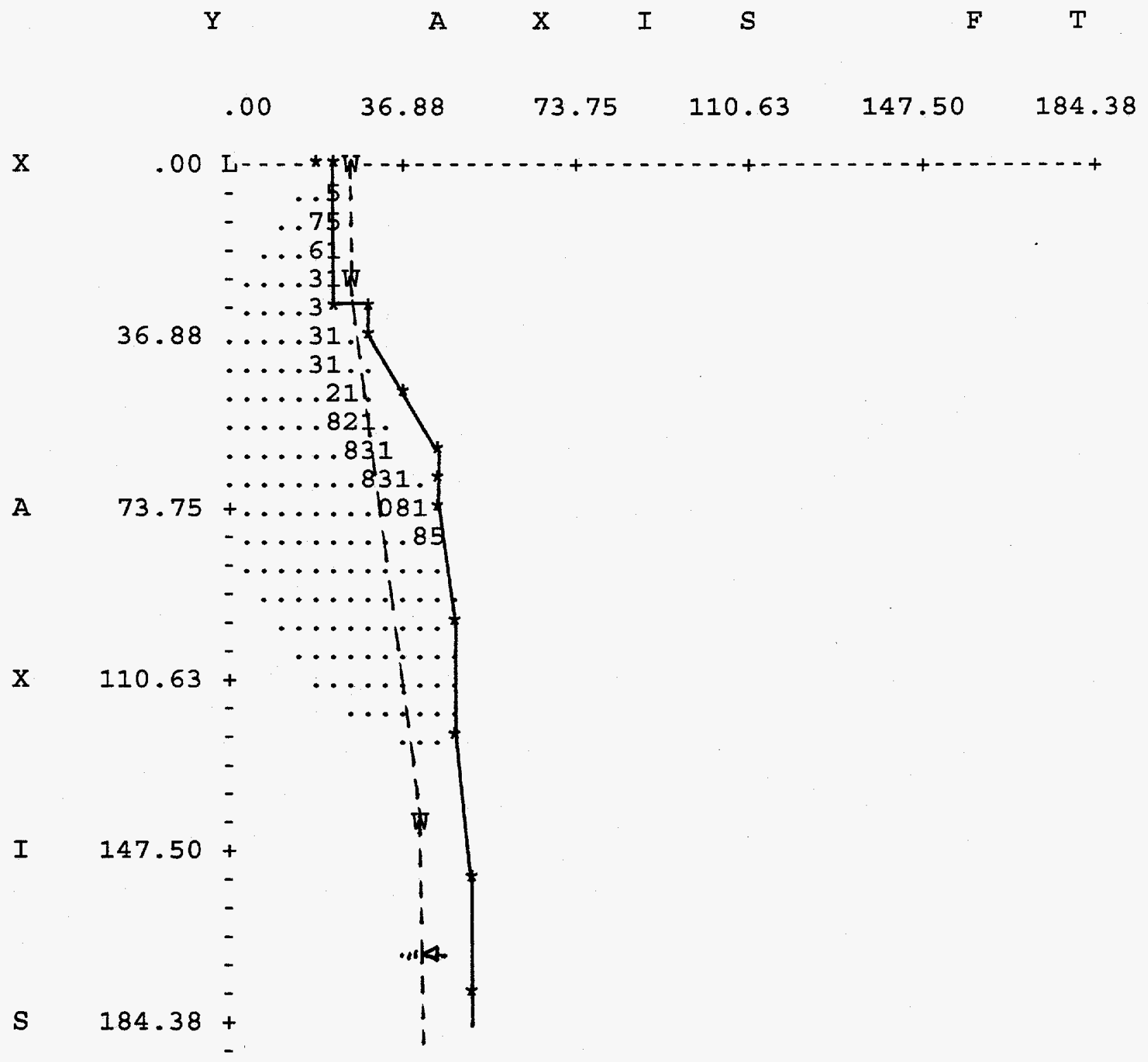




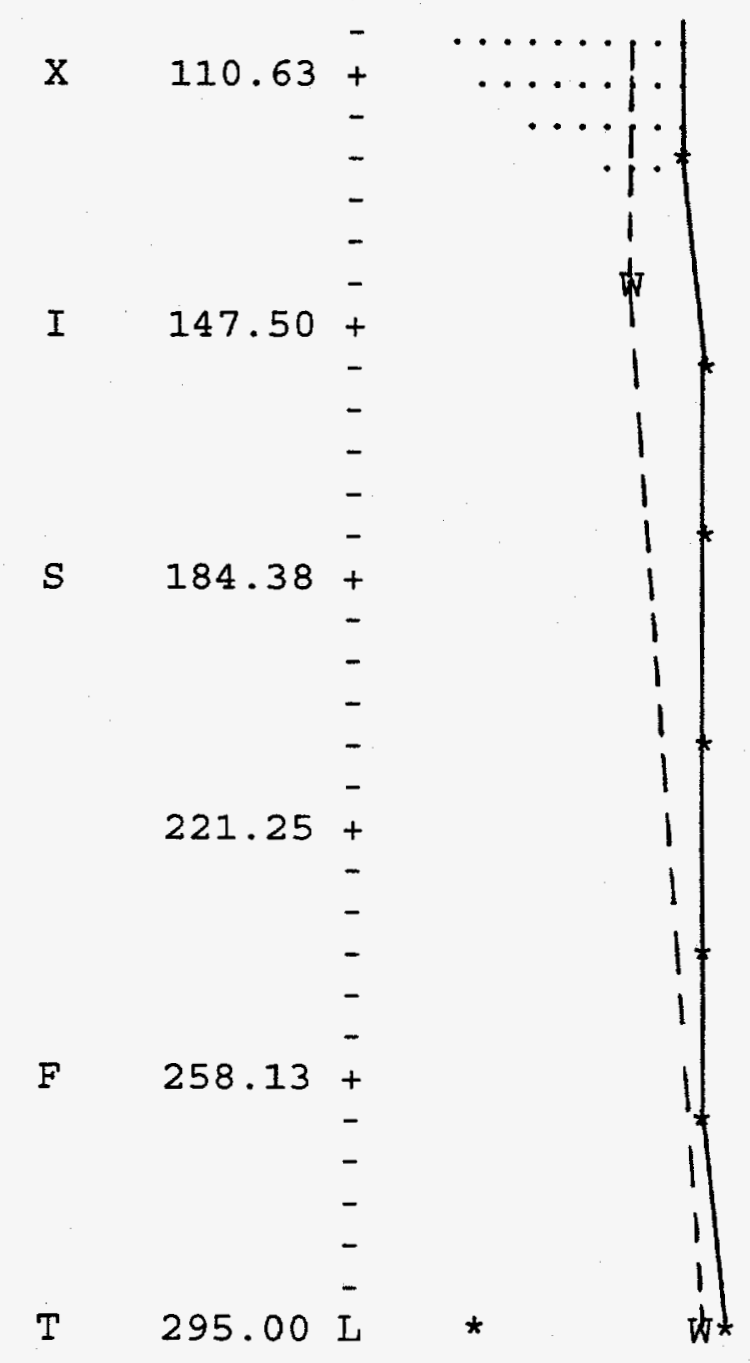

A-10 
Canonsburg, Mounts, Section A w/erosion Soil 26.8 deg \& 120 pcf, EQ = 0. . Ten Most Critical. A:CANOM.PLT By: John Lommler 12-69-94 8:37am

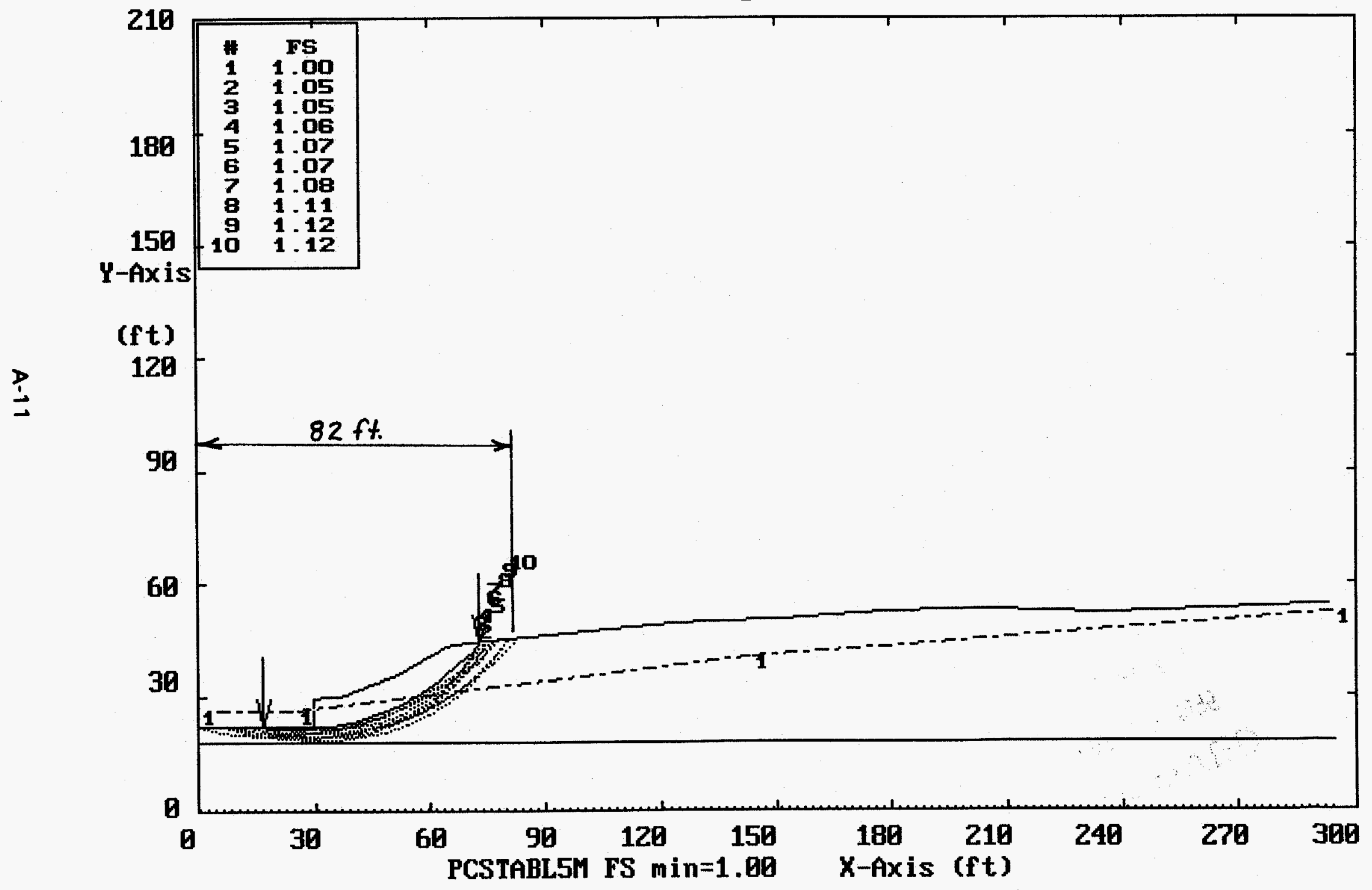

